\title{
The Growing Influence of Economics and Economists on Antitrust: An Extended Discussion
}

\author{
Lawrence J. White ${ }^{*}$ \\ Stern School of Business \\ New York University \\ Lwhite@stern.nyu.edu
}

Corrected draft: $1 / 24 / 08$

Comments welcomed

\begin{abstract}
$\underline{\text { Abstract }}$
Over the past two to three decades economics has played an increasingly important role in the development of U.S. antitrust enforcement and policy. This essay first reviews the major facets of U.S. antitrust enforcement and next reviews the ways in which economics -- starting from a low base -- has grown in importance in antitrust. The essay then highlights three antitrust areas in which the influence of economics has had the greatest influence: merger analysis, vertical relationships, and predatory pricing. The essay concludes with the identification of four antitrust areas where further economics analysis could have high returns.
\end{abstract}

Keywords: Antitrust; industrial organization; merger analysis; vertical relationships

JEL Codes: K21; L40; L41; L42

\footnotetext{
* The author was the Chief Economist in the Antitrust Division of the U.S. Department of Justice, 1982-1983. An earlier version of this paper was presented at the AEA session "Better Living through Economics (V)", New Orleans, January 5, 2008. Thanks are due to Kenneth Elzinga, the discussant at that session, and to William Baumol, William Comanor, Kenneth Elzinga, Frank Fisher, George Hay, Roger Noll, Sam Peltzman, F.M. Scherer, Geoffrey Shepherd, John Siegfried, Martin Spechler, and Oliver Williamson for helpful comments on an earlier draft.
} 


\title{
The Growing Influence of Economics and Economists on Antitrust: An Extended Discussion
}

\author{
Lawrence J. White \\ Stern School of Business \\ New York University \\ Lwhite@stern.nyu.edu
}

"Over the years, our courts have increasingly turned to economic principles to guide their interpretation of the antitrust laws... Relying on economic analysis is now routine for U.S. courts in the antitrust arena -- a salutary development helping our courts make sound decisions... Another area where economics has a profound impact is within the Antitrust Division..." Barnett (2007)

\section{Introduction}

Antitrust policy in the United States is an interesting amalgam. There is, of course, a body of legislated law, starting with three important statutes: the Sherman Act of 1890, the Clayton Act of 1914, and the Federal Trade Commission Act of 1914.

Next, because the language in these statutes is extraordinarily broad and terse (at least by modern legal standards), more than a century of numerous legal decisions by courts have interpreted and given specific meaning to the broad language of the statutes.

Further, decisions by the federal enforcement agencies -- the Antitrust Division of the U.S. Department of Justice (DOJ), and the Federal Trade Commission (FTC) -- as to whether to pursue cases or to decline their prosecution ${ }^{1}$ provide another facet to antitrust policy.

Finally, economics and economists also play an important role (Kovacic 1992; FTC 2003; Barnett 2007). In principle, the antitrust laws -- at least in their modern interpretation ${ }^{2}$-- are intended to encourage competition and to thwart cartels/price-fixing and to discourage the

\footnotetext{
${ }^{1}$ This is frequently described as the exercise of "prosecutorial discretion".

${ }^{2}$ Historically a second strain of antitrust was present: American populism, with its fears of bigness and its goal of keeping economic institutions small and locally oriented. That strain has disappeared from current enforcement and interpretation.
} 
unwarranted creation and exercise of market power (which is often paraphrased as "monopoly power"). Competition and monopoly have been bedrock concepts in the liturgy of microeconomics for over a century. Therefore, the influence of economics on antitrust policy would seem to be a natural phenomenon.

As this essay illustrates, however, the influence of economics on antitrust is a relatively recent phenomenon; it was not considered to be so "natural" as recently as three or four decades ago. As of the early 1960s, for example, the two enforcement agencies had few well-trained economists on their staffs, and the appearance of an economist as an expert in support or testifying on behalf of the plaintiffs or defendants in antitrust litigation was rare. Today, by contrast, both agencies have sizable staffs of well-trained economists, and most antitrust cases of any kind have economists involved on one or both sides. Indeed, in response to this "demand", a number of specialty antitrust economics consulting firms have arisen to offer a "supply".

The rest of this essay will expand on these developments, as follows: In Section II we will provide a brief overview of the antitrust laws. Section III will trace the growth of the influence of economics and economists over the past century. Section IV will pay special attention to three areas on which economics has had the most influence -- merger analysis, vertical restraints, and predatory pricing. Section V offers a brief conclusion and highlights some areas where further economic analysis could still yield high returns.

\section{A Brief Overview of U.S. Antitrust Policy}

There are three major thrusts to modern antitrust enforcement in the U.S.: ${ }^{3}$ First are the

3 Arguably, there is a fourth thrust as well: restrictions on price discrimination, under the Robinson-Patman Act, which was a 1936 strengthening of Section 2 of the Clayton Act. However, the DOJ has not brought a Robinson-Patman lawsuit since the early 1960s, and the FTC's suits have declined almost (but not quite) to zero (Kovacic 2003); private plaintiffs rarely win the few cases that they bring. The Antitrust Modernization Commission (2007), which was tasked by Congress with recommending modifications in the antitrust laws, recommended outright repeal of the 
efforts to prevent "collusion": explicit price fixing or bid rigging or cartel formation. ${ }^{4}$ These efforts mostly consist of law suits brought by the DOJ and by private parties under Section 1 of the Sherman Act, which forbids "every contract, combination in the form of trust or otherwise, or conspiracy, in restraint of trade or commerce among the several States or with foreign nations..." Violations of the Sherman Act are felonies, which means that the DOJ can seek jail terms against individuals and sizable fines against companies. Private parties that claim to have been harmed directly by price-fixers can also bring suits (regardless of whether there have been any suits by the DOJ or FTC), with any proven damages being automatically trebled.

Second are efforts to prevent mergers, where their effect would be to cause a significant lessening of competition. These are primarily suits brought by the DOJ or the FTC under Section 7 of the Clayton Act, which forbids mergers "where in any line of commerce in any section of the country, the effect of such acquisition may be substantially to lessen competition, or to tend to create a monopoly." The goal of such a suit is simply to gain an injunction to stop the merger from proceeding. $^{5}$

Third are efforts to restrain the unilateral exercise of market power by a seller (or a buyer). These are suits that can be brought by the DOJ, the FTC, or private parties. Section 2 of the Sherman Act (under which suits by the DOJ and private parties are authorized), forbids acts that "monopolize, or attempt to monopolize... any part of the trade or commerce among the Several States, or with foreign nations..." Again, the Sherman Act allows felony convictions, although the

Robinson-Patman Act.

${ }^{4}$ Although most antitrust enforcement efforts are phrased in terms of preventing anti-competitive acts by sellers, antitrust enforcement applies (in principle) equally to anti-competitive acts by buyers (and thus to the exercise of monopsony power as well as monopoly power).

${ }^{5}$ Such suits may be settled by agreements by the merging parties to divest sufficient assets so as to maintain a sufficiently competitive environment. 
DOJ more often brings civil suits that seek injunctions in this area. And, again, private trebledamages lawsuits can be brought.

In addition, the FTC has, under the auspices of Section 5 of the Federal Trade Commission Act, the ability to prevent "unfair methods of competition in or affecting commerce, and unfair or deceptive acts or practices in or affecting commerce." And, finally, the DOJ, the FTC, and private parties can bring suits aimed at tying, bundling, exclusive dealing, and similar vertical restraints under the auspices of Section 3 of the Clayton Act, which forbids efforts "to lease or make a sale or contract for sale of goods....within the United States....or fix a price charged therefor, or discount from, or rebate upon, such price, on the condition, agreement, or understanding that the lessee or purchaser thereof shall not use or deal in the goods....of a competitor or competitors.....where the effect....may be to substantially lessen competition or tend to create a monopoly in any line of commerce."

In addition to prosecuting antitrust law violations, the DOJ and the FTC pursue procompetition policies in three other, less well known ways: First, they frequently file "amicus" (friend of the court) briefs in privately filed antitrust cases that have reached appellate levels, especially cases reaching the Supreme Court. Since the number of private cases filed annually is approximately ten times the number of cases brought by the two enforcement agencies (Viscusi et al. 2005, p. 72), and private cases can yield legal precedents that are as binding as agency-filed cases, these amicus briefs give the agencies the opportunity to "lobby" the courts in favor of procompetitive decisions.

Second, the DOJ and FTC engage in "competition advocacy": the advocacy of procompetitive policies for other federal agencies in regulatory proceedings and for the 50 states in their regulatory actions. For example, in the past few years both the DOJ and the FTC have been urging the states (with only partial success) to eschew regulatory policies that would protect "full-service" 
residential real estate brokers from the competition offered by "discount" brokers. ${ }^{6}$

Third, as other countries (especially in the wake of the transition of Eastern European countries to market-oriented economies) have become more interested in developing antitrust policies of their own, the two U.S. enforcement agencies have provided international advice and technical assistance.

\section{Economics and Economists' Involvement in Antitrust -- A Brief History $^{7}$}

The influence of economics on antitrust has occurred along three paths: (a) advances in economics thinking -- as expressed in theoretical developments and empirical testing -- about the microeconomics that undergirds antitrust; (b) the direct involvement of economists in antitrust litigation and policy development at the enforcement agencies and in the service of private parties that have been plaintiffs or defendants in antitrust cases; and (c) economists' writings about specific antitrust cases, including those in which they provided litigation support. This section will trace these three paths.

\section{A. The development of economics thinking.}

Prior to the 1930s it would be difficult to identify a body of economics thought that could be identified as "industrial organization" (IO). ${ }^{8}$ By the end of the 1930 s, however, the field was starting

\footnotetext{
${ }^{6}$ See, for example, Hahn et al. (2006) and White (2006b).

${ }^{7}$ This section draws on parts of White (1999).

${ }^{8}$ I have been unable to determine when the phrase "industrial organization" was first used to describe the specific field of microeconomics that has now come to be associated with that phrase or when the phrase came into common use for describing the field. I have found a 1937 journal article title that comes close: "The Organization of Industry and the Theory of Prices" (Burns 1937). Marshall (1920, Book IV, chs. VIII-XII)) does have five chapters that have the words "industrial organization" in their titles; but these chapters focus on issues of the firm (such as economies and diseconomies of scale) rather than on issues of industry and markets. Schumpeter (1954, pp. 948950), in discussing the "contributions of the applied fields" to the development of economics thought "from 1870 to 1914 (and later)" briefly discusses the category of "railroads, public utilities, 'trusts,'
} 
to coalesce and take shape. ${ }^{9}$ Partly this was due to the influence of Edward Mason at Harvard (Mason 1939, 1957) and his colleagues and Ph.D. students ${ }^{10}$ (who included, in the 1930s and afterward, Donald Wallace, William Nichols, Jesse Markham, Merton J. Peck, Samuel Loescher, Richard Tennant, James McKie, Joe Bain, Carl Kaysen, Morris Adelman, Donald Turner, and Richard Caves), and partly this was due to the industrial data collection and analyses that emerged from the Temporary National Economic Committee (TNEC). ${ }^{11}$

The field continued to develop over the next few decades. By the 1950s the structureconduct-performance (S-C-P) model -- with the central role of seller concentration as a determinant of industry conduct and performance -- was the mainstay of IO thinking. In addition, formal thinking about oligopoly (e.g., Chamberlin 1929, 1956, ch. 3; Fellner 1949, Stigler 1964), aided by insights from game theory (e.g., Shubik 1959; Schelling 1960) and especially the "prisoner's dilemma", helped support the central role of concentration. The role of entry in the model gained prominence in the 1950s (Bain 1954, 1956). Empirical testing of the relationship between industry

and cartels"; but all of his discussion is focused on railroad and public utility economics. See more generally the discussion in De Jong and Shepherd (2007).

${ }^{9}$ In 1942 when a collection of articles was published by the AEA (1942), titled Readings in the Social Control of Industry and reprinting a collection of 15 articles on IO-oriented topics that were published between 1934 and 1940, none of the articles had "industrial organization" in its title, although the Burns (1937) article was among them; but the "Preface" to the volume (Homan 1942, pp. v-vi) mentioned that the selection of the articles followed "the principle of confining attention to the more general problems of public policy toward industrial organization and control..." See also Peltzman (2007).

10 See Shepherd (2007); and see De Jong and Shepherd (2007) more generally for minibiographies of some of the leading figures in IO during the 1930s and after.

11 The TNEC was created by an act of Congress in June 1938 and ended in April 1941. In its three years of existence it generated 37 volumes of testimony, two volumes of recommendations, and 43 monographs. Its data collection efforts provided the precedent for the Census of Manufactures, which first published data for 1947. For an example of its monographs, see Wilcox (1940). 
profit rates as a dependent variable and structural characteristics of the various industries as the independent variables, using the Censuses of Manufactures as the central data source, provided empirical support for the model (Bain 1951), as did a large number of industry study monographs. ${ }^{12}$ By the end of the 1950s, Bain's (1959) IO text laid out the S-C-P paradigm in systematic form, while the Kaysen and Turner (1959) treatise on antitrust provided an extensive application of the

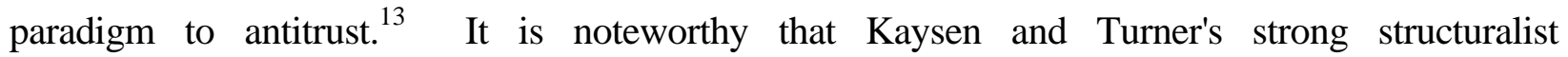
deconcentration remedies for oligopolistic industries rested heavily on Bain's $(1954,1956)$ finding that economies of scale, though a significant barrier to entry in many industries, did not appear to extend to the sizes of the largest firms in these industries -- with the implication that antitrust-forced divestitures would involve little or no sacrifice in productive efficiencies.

It is important to mention that a second strand of IO analysis was developing in the 1950s, under the intellectual leadership of Aaron Director (Peltzman 2005). This strand was more skeptical of the S-C-P paradigm, more sympathetic to vertical restraints, and generally more supportive of market outcomes. The economics scholars that were associated with Director included Milton Friedman, George Stigler, Sam Peltzman, Lester Telser, Harold Demsetz, John McGee, Ward Bowman, and Meyer Burstein.

Government antitrust victories, and the judicial opinions that supported those victories, in Sherman Section 1 and Section 2 cases in the 1940s and 1950s involving the aluminum industry, the cigarette industry, the movie industry, and the shoe machinery industry reflected these developments of the S-C-P paradigm. Only in the movie industry, however, were there major divestitures as remedies -- but these involved vertical separations, not the horizontal divestitures envisioned by

\footnotetext{
12 See Grether (1970) for a listing.

${ }^{13}$ By the late 1950s and early 1960s the S-C-P paradigm was also being applied to regulated industries; see, for example, Meyer et al. (1959) and Caves (1962).
} 
Kaysen and Turner. ${ }^{14}$

Further, after being largely dormant because of unduly restrictive wording in its original legislative language, Section 7 of the Clayton Act was revived by the Celler-Kefauver Amendment in 1950. A remarkable two-decade series of government challenges to mergers -- mostly victorious - followed, based largely on S-C-P grounds (although some elements of populist fears of bigness were also present). ${ }^{15}$

The 1960s and early 1970s saw further elaborations of the S-C-P paradigm and more extensive testing of the profitability-concentration relationship, with the inclusion of entry conditions (e.g., Mann 1966; Comanor and Wilson 1967; Collins and Preston 1968, 1969; Weiss 1971), ${ }^{16}$ advertising (e.g., Comanor and Wilson 1967, 1974), foreign trade (e.g., Esposito and Esposito 1971), the structural conditions on the buyers' side of the market (e.g., Lustgarten 1975), risk (e.g., Bothwell and Keeler 1975), and the presence of a critical concentration ratio (e.g., White 1976). ${ }^{17}$ But a

${ }^{14}$ Also, in U.S. v. E.I. de Nemours and Co. et al., 353 U.S. 586 (1957) the Supreme Court ruled that du Pont had to divest its 23\% stock ownership in General Motors; but again, this was a vertical separation.

15 The major cases in this series included: U.S. v. Bethlehem Steel Corp. et al., 168 F. Supp. 576 (1958); Brown Shoe Co. v. U.S., 370 U.S. 294 (1962); U.S. v. Philadelphia National Bank et al., 374 U.S. 321 (1963); U.S. v. Aluminum Company of America et al., 377 U.S. 271 (1964); U.S. v. Continental Can Co. et al., 378 U.S. 441 (1964); FTC v. Consolidated Foods Corp., 380 U.S. 592 (1965); U.S. v. Von's Grocery Co. et al., 384 U.S. 270 (1966); U.S. v. Pabst Brewing Co., 384 U.S. 546 (1966); FTC v. Proctor \& Gamble Co. et al., 386 U.S. 568 (1968); Citizen Publishing Co. v $\underline{\text { U.S., }} 394$ U.S. 131 (1969); and U.S. v. Falstaff Brewing Corp., 410 U.S. 526 (1973). It was in Von's that Justice Potter Stewart, in dissent, made a remark that seemed to typify the government's success in challenging mergers: "The sole consistency that I can find is that in litigation under Section 7, the government always wins", 384 U.S. 270, 301 (1966).

${ }^{16}$ Also, see the later surveys of entry that are to be found in Siegfried and Evans $(1992,1994)$ and Geroski (1995).

17 See Weiss (1971, 1974), Bresnahan (1989), Schmalensee (1989), and Caves (2007) for summaries. 
"Chicago School" counter-revolution was brewing as well, which argued that high concentration might be causing high profit rates, because of economies of scale (contrary to the earlier claims by Bain). ${ }^{18}$ The famous "face-off" of the S-C-P advocates versus the Chicago School in the early 1970s led to the publication of a widely read and cited conference volume (Goldschmid et al. 1974).

A further blow to the profit-concentration empirical support for the S-C-P model came in the early 1980s, from two major attacks (Benston 1982; Fisher et al. (1983); Fisher and McGowan 1983; Fisher 1984, 1987) on the use and reliability of the accounting data that were used to measure the profit rates used in the studies and on whether relative profit rates were even the appropriate indicators of market power. Profit-based tests of the S-C-P paradigm quickly tailed off, but were soon replaced by price-based studies drawn from individual industries (e.g., as summarized in Weiss 1989; Audretsch and Siegfried 1992), which tended to show a similar positive relationship between prices and concentration. In addition, empirical studies of auctions indicated that the number of bidders at auctions (which, say, in procurement auctions would be an approximate equivalent to the number of sellers in a market) would have the same type of effect on prices (e.g., Brannman et al. 1987; Brannman and Klein 1992).

As is discussed in Section IV below, the S-C-P paradigm, with some further economicsbased supplements, became the basis for much of the modern version of the DOJ (and now DOJFTC) "Merger Guidelines".

In the area of vertical relationships, too, there was a clash between the "Harvard" tradition and the "Chicago" tradition. The former was suspicious of -- and tending to hostility toward -vertical mergers (e.g., between suppliers and customers) and vertical restraints (e.g., tying, bundling, exclusive dealing, territorial sales restraints, resale price maintenance). As will be discussed in Section IV, until the early 1970s antitrust legal decisions were generally hostile toward vertical

\footnotetext{
${ }^{18}$ See Demsetz (1973, 1974).
} 
mergers and vertical restraints, but since then the line of economic reasoning that was championed by the Chicago School has generally prevailed in the courts.

Finally, it is worth noting that a number of IO-oriented professional economics journals came into existence, providing specialized vehicles for the dissemination of the research in IO. Included in this list (with their first year of publication) would be: Journal of Industrial Economics (1952); Antitrust Bulletin (1955); Journal of Law \& Economics (1958); $\underline{\text { RAND Journal of }}$ $\underline{\text { Economics (1970); }{ }^{19} \text { Review of Industrial Organization }(1977) ;{ }^{20} \text { International Journal of Industrial }}$ Organization (1984); Journal of Regulatory Economics (1984); and Journal of Economics \& Management Strategy (1992). Also, a first-ever Handbook of Antitrust Economics (Buccirossi 2007) is another milestone in the maturation of economics thought as applied to antitrust. ${ }^{21}$

B. The role of economists at the enforcement agencies and in antitrust litigation.

Economists' direct involvement in antitrust extends back at least to the beginning of the twentieth century, ${ }^{22}$ although their role prior to the 1970 s was often limited to simple litigation support -- in a sense, as "hewers of wood and haulers of water" -- rather than being able to participate in the development of case theories and the formulation of policy.

${ }^{19}$ The RJE was originally (1970) the Bell Journal of Economics and Management Science, then (1975) the Bell Journal of Economics, and then (1984) the RJE.

${ }^{20}$ The $\underline{\mathrm{RIO}}$ was originally the Industrial Organization Review. It became the $\underline{\mathrm{RIO}}$ in 1984.

${ }^{21}$ That the appearance of this volume marks a milestone in the relationship of IO to antitrust is highlighted by the fact that there was not even a chapter devoted to antitrust economics in the original two-volume Handbook of Industrial Organization (Schmalensee and Willig 1989a, 1989b). There was a section in the second volume that was devoted to "Government in the Marketplace". But all five chapters in that section (Noll 1989; Braeutigam 1989; Baron 1989; Joskow and Rose 1989; and Gruenspecht and Lave 1989) were focused on regulation, not antitrust.

${ }^{22}$ As Letwin (1965, pp. 71-77) and Scherer (1970, p. 424) have noted, economists in the 1880s were generally unconcerned about the rise of the "trusts" and thus were not advocates of passage of the Sherman Act. 
The U.S. Bureau of Corporations, which had been established in 1903 within the Department of Commerce and Labor and which had economists on its staff, provided valuable research support for some of the early antitrust prosecutions undertaken by the DOJ, including U.S. v. Standard Oil Co., 221 U.S. 1 (1911), and U.S. v. American Tobacco Co., 211 U.S. 106 (1911) (Scherer 1990). An early -- possibly, the first -- testimony by an economist in an antitrust case was in U.S. v. United States Steel Corp., 223 F. Rep. 55, 251 U.S. 417 (1920), which was filed in October 1911 and ultimately decided by the Supreme Court in 1920 against the DOJ. The Supreme Court's decision disparagingly cited the testimony of "an author and teacher of economics whose philosophical deductions had, perhaps, fortification from experience as Deputy Commissioner of Corporations and as an employee in the Bureau of Corporations." (251 U.S. 417, 448)

When the FTC was created in 1914, its Economic Department (later to become the Economic Division and then the Bureau of Economics, which is the title it retains today) inherited the Bureau of Corporations' research and investigative role, as well as absorbing the specific office accommodations and personnel of its predecessor agency (Scherer 1990). ${ }^{23}$

At the DOJ the responsibility for antitrust enforcement was placed in a separate division -the Antitrust Division, where that responsibility still rests -- only in $1933 .^{24}$ Within three years the Division hired its first economists (White 1984). Until the early 1970s, however, the economics group within the Division was used primarily for data gathering and statistical support in litigation. Posner's (1971, p. 532) study of the Division offered the following description: "...the Division's

${ }^{23}$ See also Blaisdell (1922), Henderson (1924), Stevens (1940), and Mueller (2004).

24 The DOJ acquired antitrust enforcement authority under the Sherman Act in 1890. Until 1903 enforcement was carried out directly within the Office of the Attorney General, and from 1903-1933 it was carried out within the Office of the Assistant to the Attorney General (White 1984). According to Edwards (1940), who cited Thurman Arnold, "the great trust-busting campaign of Theodore Roosevelt [which included the filing and litigation of the Standard Oil, American Tobacco, and other important antitrust cases] was conducted with 7 lawyers and 4 stenographers." 
economists today are handmaidens to the lawyers, and rather neglected ones at that." Another study of the Division in the early 1970s (Green 1972, p. 128) characterized economists there as "...second class citizens. They have little or no say in the type of cases brought, the legal theories used, or the relief sought. In general, they neither conduct long-range studies nor work closely with the policyplanning staff. Mostly they aid attorneys in the preparation of statistical data for trial, and they occasionally testify. They are technicians -- "statisticians," as nearly all of the lawyers call them -and act like it." A later study (Weaver 1977) mentioned economists only in passing -- again an indication of their subsidiary role.

In the mid 1960s the Assistant Attorney General for Antitrust, Donald Turner (who had a Ph.D. in economics from Harvard as well as a law degree), established the position of Special Economic Assistant to the Assistant Attorney General, and a number of young industrial organization economists -- William Comanor, Oliver Williamson, William G. Shepherd, H. Michael Mann, Leonard Weiss, Kenneth Elzinga, George Eads, and George Hay -- served one-year terms in the position. ${ }^{25}$ But, until the early 1970s, little was done to strengthen the quality and position of the staff economists at the Division, as reflected in the descriptions above.

At the FTC the tradition that had started at the Bureau of Corporations served economics and economists somewhat better. The Bureau of Economics (BE) was able to attract Ph.D.-trained leaders, such as Corwin Edwards, John Blair, Jesse Markham, and Willard Mueller, and during the 1960s the size and budget of BE expanded considerably (Mueller 2004). Nevertheless, at the end of the 1960s outside reviews of the FTC (ABA 1969; Green 1972) commented unfavorably on the low quality of BE's personnel and on BE's lack of influence on policy and decision-making within the agency. $^{26}$

\footnotetext{
${ }^{25}$ For a discussion of this era, see Williamson (2003).

${ }^{26}$ For a different view, see Mueller (2004).
} 
Two top-level committee reviews of general antitrust policy at the end of the 1960s viewed economics and economists quite differently. The "Neal Report" (White House 1968) was largely silent on the subject, although it did endorse improvements in the gathering of economic information by the enforcement agencies. The "Stigler Report" (Task Force 1969), on the other hand, strongly endorsed an expanded role for economics and economists at the Antitrust Division and at regulatory agencies more widely.

The 1970s brought a general strengthening of the position of economists at the two enforcement agencies and in antitrust litigation support. ${ }^{27}$ At the FTC a reorganization and reform of the agency strengthened the position and status of BE. During the decade H. Michael Mann, F.M. Scherer, Darius Gaskins, and William Comanor served as BE Directors. Commentaries at the end of the 1970s (Katzmann 1980; Clarkson and Muris 1981) noted the strengthened position of BE. At the DOJ in 1973 George Hay, completing his one-year term as Special Economic Assistant, convinced the Division to strengthen the Economics Section and transform it into the Economic Policy Office, with Hay as its initial director and with authority to expand its personnel and recruit Ph.D. economists to staff positions (Kauper 1984). ${ }^{28}$

More generally, the 1970s saw an increased involvement of economists in antitrust cases; sometimes the economists' involvements led to publications that reviewed the economic issues of the specific cases in which they had been involved. These writings will be discussed below.

The involvement of economists in antitrust policy, as well as litigation support, took a sharp turn upward in the early 1980s, with the arrival at the Antitrust Division and the FTC of leaders who

${ }^{27}$ Kwoka and White (1989, 1994, 1999, 2004a, 2009) have written about the "revolution" of the application of economics reasoning to antitrust in the 1970s and afterward and enlisted economists who participated in major antitrust cases to write analyses of the cases in which they were involved. Some of the 1970s cases are discussed below.

${ }^{28}$ See also Eisner (1991). 
were quite sympathetic to the role and message of microeconomics in the development of antitrust policy and in litigation. ${ }^{29}$ For the first time there were FTC Commissioners who were economists, including the Chairman during the first few years of the Reagan Administration. The FTC continued to have an economist as at least one of its five commissioners during 1981-1985 and 1991-1995. At the Division, an indication of the rising importance of economists in the mid 1980s was the elevation of the position of Director of the Economic Policy Office to a Deputy Assistant Attorney General.

As of the first decade of the twenty-first century, economists continue to play prominent roles at both agencies (see, e.g., FTC 2003; Barnett 2007; Salinger et al. 2007; Carlton and Heyer 2007). At the DOJ, there are approximately 60 Ph.D.-level economists, headed by a Deputy Assistant Attorney General who is usually a leading academic IO economist and who typically serves for about two years in the position. Similarly at the FTC, the BE is staffed by approximately 70 Ph.D.-level economists (although about a quarter of their time is spent on consumer protection issues), and the Bureau Director is usually a leading academic economist who spends about two years in the position.

\section{Economists' writings about specific antitrust cases.}

The tradition of economists' writing specifically about major antitrust cases extends at least as far back as a 1949 symposium in the American Economic Review (Adelman 1949a; Nicholls 1949); Nicols 1949) ${ }^{30}$ and includes Stocking and Mueller's (1955) discussion of the "cellophane fallacy" of U.S. v. E. I. du Pont de Nemours \& Co., 118 F. Supp 41 (1953), 351 U.S. 377 (1956).

${ }^{29}$ Also in the late 1970 s and the 1980s the number of economics consulting firms that had extensive antitrust litigation support practices increased substantially. Often these firms were led and staffed by "alumni" from the economics staffs of the two enforcement agencies.

30 The cases about which they were writing were, respectively, U.S. v. New York Great Atlantic \& Pacific Tea Co. et al., 173 F.2d 79 (1949); American Tobacco Co. et al. v. U.S., 147 F. 2d 93 (1944), 328 U.S. 781 (1949); and FTC v. Cement Institute et al., 333 U.S. 683 (1948). See also Adelman (1949b). 
Most of the antitrust discussions prior to the 1970s were by economists who had simply become interested in the details and implications of a particular antitrust case. A notable exception was Carl Kaysen, who in 1950 as a Ph.D. student of Edward Mason's at Harvard provided a unique form of antitrust litigation support: He was appointed as a law clerk by Federal District Court Judge Charles Wyzanski, to provide economic counseling to Judge Wyzanski in the DOJ's monopolization trial of the United Shoe Machinery Company. ${ }^{31}$ Kaysen served for two years and wrote a lengthy report for Judge Wyzanski, which subsequently became Kaysen's Ph.D. dissertation and a monograph (Kaysen 1956).

By the 1970s economists were actively participating in antitrust cases more frequently and then writing about those cases. ${ }^{32}$ Such instances in cases that were initiated in the late 1960 s and the 1970s included Fisher et al. (1983), DeLamarter (1986), and Houthakker (1999) on the DOJ's monopolization suit against IBM; Brock (1989) on private suits against IBM; Evans (1983) and Noll and Owen (1994) on the DOJ's suit to break up AT\&T; Hay (1999) on the FTC's suit against the manufacturers of lead-based antiknock gasoline additives; White (1975) on the DOJ's suit alleging price-fixing of fleet automobile sales by General Motors and Ford; Schmalensee (1978) and Scherer (1979) on the FTC's investigation of the breakfast cereal industry; Hilke and Nelson (1989) on the FTC's allegations of predation in the sale of coffee; Dobson et al. on the FTC's suit concerning du Pont's monopoly of titanium oxide (1994); Cox (1989) on a private suit challenging state-imposed restrictions on advertising by lawyers; Elzinga (1999) on a private suit alleging conspiracy and predation by Japanese manufacturers of televisions; Preston (1994) on a private suit challenging

${ }^{31}$ U.S. v. United Shoe Machinery Corp., 110 F. Supp. 295 (1953), 347 U.S. 521 (1954).

32 The DOJ's major suits against IBM (initiated in 1969) and AT\&T (initiated in 1974) eventually involved large numbers of economists on both sides, and this widespread exposure of economists to antitrust may well have been influential in encouraging further participation in other cases and in encouraging economists' writing about antitrust cases. 
territorial restraints by GTE-Sylvania; Warren-Boulton (1999) on a private suit alleging resale price maintenance by Monsanto; and Lynk (1999) on a private suit alleging tying by Jefferson Parish (Louisiana) Hospital.

Since the 1970s economists' participation in antitrust litigation has become substantially more frequent (Kovacic 1992; Barnett 2007), and articles reflecting that participation also continue to appear (see, e.g., Kwoka and White 1989, 1994, 1999, 2004a, 2009).

\section{$\underline{\text { IV. Special Achievements }}$}

There are three areas of antitrust where economists' achievements in bringing changes in antitrust enforcement and policy are especially noteworthy: merger analysis, vertical relationships and restraints, and predatory pricing. ${ }^{33}$ Each will be addressed below.

\section{A. Merger analysis.}

Almost all of modern antitrust merger analysis takes as its starting point the DOJ-FTC Horizontal Merger Guidelines. ${ }^{34}$ The Guidelines, first published in $1982^{35}$ and subsequently revised in 1987, 1992, and 1997, establish two approaches under which a merger might be deemed to have anti-competitive consequences: "coordinated effects" and "unilateral effects".

33 In addition to the major achievements mentioned in the text, "honorable mention might include: (a) Antitrust economists were among the early advocates of the economic deregulation of securities and banking markets, transportation markets, telecommunications markets, and energy markets; see, for example, Eads (1975), Mann (1975), and Weiss (1975); (b) Antitrust economists have been major advocates for larger fines and the continuation of treble damages in private antitrust suits as instruments for deterrence; see for example Salop and White (1986, 1988); and (c) Antitrust economists have been major advocates of the repeal of the Robinson-Patman Act; see, for example, Adelman (1949a, 1949b, 1959).

${ }^{34}$ Accessed at: http://www.usdoj.gov/atr/public/guidelines/hmg.htm

35 An earlier set of DOJ Guidelines were published in 1968 but proved unsatisfactory and were largely scrapped when the 1982 Guidelines were adopted. The economists at the DOJ played an extensive role in the development of the 1982 Guidelines, especially the market definition paradigm that is discussed below; see White (2000). 
1. Coordinated effects. This is a direct application of the S-C-P model, with the special emphases that were provided by Stigler (1964). The primary concern under this approach is that oligopolistic sellers will, post-merger, be able implicitly to coordinate their behavior so as to achieve significantly higher prices (or to effect other changes in conduct variables) and higher profits. Seller concentration, as measured by the Herfindahl-Hirschman Index (HHI), ${ }^{36}$ occupies the center stage (as it does in the S-C-P model) for at least two reasons: First, seller concentration is surely the most readily measured structural attribute; and second, the immediate effect of any horizontal merger is to increase seller concentration. The Guidelines indicate specific guideposts as to post-merger concentration (and merger-induced changes in concentration) that will likely trigger close scrutiny and possible intervention. ${ }^{37}$

The Guidelines also bring into the analysis the other important components of the S-C-P model: conditions of entry; the buyer side of the market; the nature and complexity of the product; the transparency (or opaqueness) of price and other market information; and the antitrust history of the sellers in the market.

A particular problem of implementing merger enforcement prior to 1982 had been the issue of defining the relevant product and geographic markets. The S-C-P model assumes that an appropriate market has been specified, so that the market shares of the leading firms provide a meaningful indication of the likelihood that the firms will collectively exercise market power. But the S-C-P model itself provides no guidance for delineating appropriate markets.

36 The HHI was used as the measure of seller concentration in the Guidelines, rather than the four-firm concentration ratio (which was far more commonly used prior to 1982), partly because it is a more complete measure of the shares of all firms in the market and partly because Stigler (1964) showed that it could serve as an indicator of the ease with which sellers who were trying to coordinate their pricing could distinguish between random market share fluctuations and the market share changes that could occur as a consequence of a surreptitious price cut.

37 Actual enforcement, however, has indicated that substantially higher HHI levels are the de facto thresholds. See Leddy (1986), Coate (2005), and Coate and Ulrick (2005). 
The Guidelines addresses this problem in the following way: A relevant market is defined as a product or group of products that are sold by a group of sellers who, if they acted in concert (i.e., as a "hypothetical monopolist"), could achieve a "small but significant and nontransitory increase in price" (SSNIP); that SSNIP is designated as 5\% for one year. This is equivalent to defining a relevant market as one in which market power can be exercised (or one in which market power can be enhanced). ${ }^{38}$ The smallest group of sellers that satisfies the SSNIP test is usually designated as the relevant market. These principles apply to the determination both of product markets and of geographic markets. The determining factor in the analysis is whether sufficient numbers of buyers would switch away to other sellers (of other goods and/or located in other areas) so as to thwart the price increase.

The logic of this approach follows from the goal of preventing mergers that create or enhance market power. The SSNIP test identifies the smallest group of sellers who could exercise such power. With one exception, the market definition paradigm focuses on sellers (since it is sellers who exercise market power). That exception arises when a group of sellers may be able to practice price discrimination and raise prices significantly for an identifiable group of buyers (defined by a geographic area or by a business function). In such a case, that group of buyers may also be considered to be a relevant market.

This market definition paradigm has proved enduring and has spawned a "mini industry" of econometric efforts in merger cases to estimate "critical" demand elasticities and price-cost margins that would indicate the boundaries of relevant markets. ${ }^{39}$

${ }^{38}$ As Werden (2003) has indicated, the first suggestion for using this approach to define relevant markets for merger analysis was by Adelman (1959). Other efforts at defining markets, such as Elzinga and Hogarty (1973) and Horowitz (1981), proved less satisfactory than the approach outlined in the text.

${ }^{39}$ See, for example, Katz and Shapiro (2003). 
2. Unilateral effects. The 1992 revision to the Merger Guidelines added "unilateral effects" as a second area of anti-competitive concern with respect to mergers. By this is meant a significant post-merger price increase that could occur solely on the part of the merged entity. This unilateral price increase could occur if the two merging firms produced products that were moderately close substitutes for each other (but not perfect substitutes) and a significant number of the customers of each firm had as their runner-up choice the products of the merger partner. If the products of all other firms were a distant enough third choice for these customers, then the merged entity would likely find a general price increase worthwhile (Ordover and Willig 1993) -- and could do even better if it could identify and target these "trapped" customers and thereby practice selective price discrimination against them. ${ }^{40}$

Note that the anti-competitive effects of this type of merger do not arise because of cooperation or collusion among the firms that compete with the merged entity. Instead the competitive harm occurs because the merged firm is better able to internalize the benefits of a price increase.

Note also that for the unilateral effects analysis the issues of market definition and market shares are largely irrelevant, since what matters is the extent to which customers have the two merging firms as their first and second choices (and the extent to which other firms are a distant third choice). Thus, direct measurements of elasticities and cross-elasticities are crucial; and, again, a mini-industry of empirical estimations for antitrust purposes has arisen. ${ }^{41}$

${ }^{40}$ Unilateral effects could also occur if a dominant firm merged with one of its rivals, even in a homogeneous goods industry (Stigler 1965). The post-merger concentration (and merger-induced change in concentration) guideposts would probably be sufficient to catch such mergers; but, to be on the safe side, the Guidelines also indicate that any merger involving a firm that has a market share of $35 \%$ or higher will receive special scrutiny.

${ }^{41}$ See, for example, Werden and Froeb (1994, 2007) and Pelcovits (2004). 
B. Vertical relationships and restraints. ${ }^{42}$

As was noted above, the "Harvard" IO tradition was hostile toward vertical relationships and vertical restraints. The important Kaysen and Turner (1959) antitrust treatise, for example, had a generally negative view of vertical mergers and of vertical restraints such as tying, ${ }^{43}$ bundling, exclusive dealing, requirements contracts, full-line forcing, territorial restraints, and resale price maintenance (RPM). ${ }^{44}$ Earlier, the Report of the Attorney General's National Committee to Study the Antitrust Laws (1955), which included economists Walter Adams, Morris Adelman, John M. Clark, Alfred Kahn, Eugene V. Rostow, Sumner Slichter, and George Stigler, ${ }^{45}$ as well as a number of leading antitrust lawyers and law professors, showed a similar harsh view of vertical restraints. ${ }^{46}$

"Chicago", however, under the intellectual guidance of Aaron Director, began offering a different view of vertical restraints. Bowman (1957) and Burstein (1960a) argued that tying was often a vehicle for monitoring the buyers' use of the tied product and thus serving as an alternative mechanism for effecting price discrimination (about which the welfare effects are generally

${ }^{42}$ An earlier treatment of this topic can be found in White (1989).

43 "...a flat rule against tying arrangements, regardless of whether they serve a useful purpose, appears justified" (Kaysen and Turner, 1959, p. 159).

${ }^{44}$ At least part of the reason for many economists' harsh view of RPM was the experience of the 1930s, when small retailers (and especially pharmacists) lobbied for protection against "unfair" competition from large chain stores. One legislative reaction, already noted above, was the Robinson-Patman Act of 1936, which strengthened the Clayton Act's Section 2 prohibitions on price discrimination (because, the small retailers alleged, the chain stores were extracting discounts from manufacturers that were unavailable to smaller retailers). Another response, the Miller-Tydings Act of 1937, authorized the states to legalize RPM (which also went by the name "fair trade"), so that the small retailers could convince manufacturers to impose RPM and thus force the chain stores to sell at the same prices as the smaller retailers.

${ }^{45}$ It is worth noting that, though Stigler was subsequently associated with the "Chicago School", at the time of the Report he was a Professor at Columbia University. See Peltzman (2007).

${ }^{46}$ White (1989) offers some reasons for these harsh views. 
ambiguous); Burstein (1960b) argued the same for full-line forcing. ${ }^{47}$ Telser (1960) argued that RPM could be a means by which a manufacturer (or other "upstream" entity) could overcome the potential free riding problems that accompany the provision of product information to customers and thereby induce more point-of-sale service from retailers. ${ }^{48}$ The free riding argument for RPM has been extended to the provision of other retailer services (Mathewson and Winter 1984; Marvel 1985; Marvel and McCafferty 1984, 1985, 1986). And free riding problems have been offered as a justification for territorial restraints (White 1981) and for exclusive dealing (Marvel 1982). Further, there was a widespread "Chicago" attack on the idea that vertical integration could generally have serious anti-competitive consequences. ${ }^{49}$

Prior to the mid 1970s, the Supreme Court's antitrust legal decisions with respect to vertical restrictions and vertical mergers were consistent with the harsh "Harvard" view. Early on, the Court condemned RPM as a per se violation of Section 1 of the Sherman Act in Dr. Miles Medical Co. v. John D. Park and Sons Co., 220 U.S. 373 (1911). ${ }^{50}$ This decision was subsequently reaffirmed in U.S. v. Bausch \& Lomb Optical Co., 321 U.S. 707 (1944); U.S. v. Parke, Davis \& Co., 362 U.S. 29

${ }^{47}$ It was also argued that tying and similar vertical restraints could be a way of making sure that the product functioned properly and thus preserving the goodwill of the manufacturer and of dealing with potential free riding problems.

48 See also Bowman (1955). Telser acknowledged that RPM could be a cover for a retailers' cartel or even for a manufacturers' cartel. What was important, however, was his demonstration that a manufacturer unilaterally might find RPM to be in its interests.

49 See, for example, Bork (1954, 1978); Bork and Bowman (1965); McGee 1971); Bowman (1973); and Posner (1976). For a discussion of some of the "counter-revolution" literature that showed that vertical restraints and vertical mergers might not be as benign as the Chicago revolution claimed, see White (1989). See also Perry (1989). For a recent summary of the empirical evidence on vertical integration, which finds primarily benign outcomes, see Lafontaine and Slade (2007).

${ }^{50}$ However, in U.S. v. Colgate \& Co., 250 U.S. 300 (1919), the Court decided that it was legal for a manufacturer to decide what the retail price of an item should be and then unilaterally decline to deal with any retailer that failed to adhere to that price. The tension between Dr. Miles Medical and Colgate remained a problem until the Leegin decision in 2007, which is mentioned below. 
(1960); Simpson v. Union Oil Co., 377 U.S. 13 (1960); and Albrecht v. Herald Co., 390 U.S. 145 (1968). ${ }^{51}$

Tying came under attack in Motion Picture Patents Co. v. Universal Film Manufacturing Co., 243 U.S. 502 (1917); ${ }^{52}$ United Shoe Machinery Corp. v. U.S., 258 U.S. 451 (1922); Carbice Corp. v. American Patent Development Corp., 283 U.S. 27 (1931); International Business Machines Corp. v. U.S., 298 U.S. 131 (1936); Morton Salt Co. v. G.S. Suppiger Co., 314 U.S. 488 (1942); and International Salt Co. v. U.S., 332 U.S. 392 (1947). In 1949 the Court condemned tying as a per se illegal offense in Northern Pacific Railway Co. v. U.S., 356 U.S. 1 (1949), and declared that "Tying agreements serve hardly any purpose beyond the suppression of competition," Standard Oil Co. of California et al. v. U.S., 337 U.S. 293, 305-306 (1949). This onslaught on tying continued in U.S. v. Loew's, Inc., 371 U.S. 38 (1962); Atlantic Refining Co. v. FTC, 381 U.S. 357; FTC v. Texaco, 393 U.S. 223 (1968); and Fortner Enterprises, Inc. v. United States Steel Corp., 394 U.S. 495 (1969).

Similarly, the Court attacked requirements contracts in Standard Oil Co. of California et al. v. U.S., 337 U.S. 293 (1949), and in Richfield Oil Corp. v. U.S., 343 U.S. 922 (1952). Earlier, the Court had attacked exclusive dealing in Standard Fashion Co. v. Magrane-Houston Co., 258 U.S. 346, and repeated that attack in Standard Oil (1949) and in FTC v. Motion Picture Advertising Service Co., 344 U.S. 392 (1953). Later, in U.S. v. Arnold Schwinn \& Co. et al., 388 U.S. 365 (1967), the Court condemned territorial restraints as a per se violation of the Sherman Act. ${ }^{53}$

And the Court condemned vertical mergers in U.S. v. E.I. du Pont de Nemours \& Co., 353

${ }^{51}$ Albrecht involved maximum RPM.

52 Prior to the 1914 passage of the Clayton Act's Section 3 prohibition on tying, the Court had upheld tying in a patented product case: Henry v. A.B. Dick Co., 224 U.S. 1 (1912).

${ }^{53}$ Four years earlier, in White Motor Co. v. U.S., 372 U.S. 253 (1963), the Court had declared that it did not know enough about territorial restrictions to be able to decide whether to condemn them or not. 
U.S. 586 (1957); Brown Shoe Co. v. U.S., 370 U.S. 294 (1962); and in Ford Motor Co. v. U.S., 405 U.S. 562 (1972).

The tide turned after the mid 1970s, ${ }^{54}$ with "Chicago" arguments largely carrying the day. In 1977 two important decisions showed the change in direction. In Continental T.V., Inc. v. GTE Sylvania, Inc., 433 U.S. 36 (1977), the Court declared that territorial restraints should be examined under a rule of reason, rather than being automatically condemned as per se illegal under the rule of

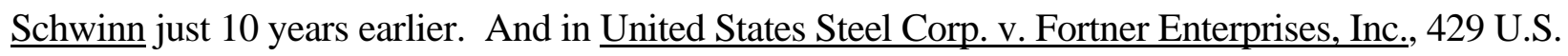
610 (1977), the Court found (reinforcing Jerrold) that the absence of market power in the tying market meant that a tying arrangement was acceptable (despite the per se rule of Northern Pacific, which remained in place).

The 1980s saw further progress. Though the Supreme Court continued its per se condemnation of RPM in Monsanto Co. v. Spray-Rite Corp., 465 U.S. 752 (1984), and in Business Electronics Corp. v. Sharp Electronics Corp., 485 U.S. 717 (1988), it raised the standard of proof that plaintiffs would need to provide in order to prevail. In Jefferson Parish Hospital District No. 2 v. Edwin G. Hyde, 466 U.S. 2 (1984), the Court again found that the absence of market power meant that a tying arrangement was acceptable; and a minority opinion signed by four members of the Court argued that the per se rule for tying should be superseded by a rule of reason approach.

In the 1990s, the Court took a step back on tying, in Eastman Kodak Company v. Image Technical Services, Inc., 504 U.S. 451 (1992), in which the Court (on a motion for summary judgment) found that Kodak must stand trial on a tying claim. However, later in the decade, in State

54 There were exceptions to the pre-1970s pattern described above. For example, in Tampa Electric Co. v. Nashville Coal Co., 365 U.S. 320 (1961), the Court declined to condemn a requirements contract and declared that exclusive dealing should be judged by a rule of reason. That same year, in U.S. v. Jerrold Electronics Corp., 365 U.S. 567 (1961), the Court affirmed a lower court opinion that allowed tying for a start-up situation. But these and a few other cases were exceptions. The general pattern was as described in the text. 
Oil v. Khan, 522 U.S. 3 (1997), the Court declared that maximum RPM should be judged under the rule of reason (and not condemned as a per se violation, as had been decided in Albrecht).

The first decade of the twenty-first century has been auspicious in this respect. In Illinois Tool Works, Inc. v. Independent Ink, Inc., 547 U.S. 28 (2006), the Court decided that the presence of a patent on the tying product does not automatically mean that the seller has market power. And in Leegin Creative Leather Products, Inc. v. PSKS, Inc., 127 S. Ct. 2705 (2007) the Court decided that minimum RPM -- the "plain vanilla" version of RPM that had been condemned as per se illegal in Dr. Miles -- should also be judged under a rule of reason.

In sum, antitrust law with respect to vertical restraints (as interpreted through Supreme Court decisions and DOJ and FTC enforcement decisions) has made great progress since the 1970s, building on the advances in economics thinking discussed above. Challenges to vertical mergers are rare, as they should be. ${ }^{55}$ Most vertical restraints are judged under a rule of reason; and even judgments concerning tying, which is still nominally a per se violation, are at least requiring a showing of market power. Where vertical restraints involve abuses and enhancements of market power, as in U.S. v. Microsoft, 253 F.3d 34 (2001), and U.S. v. Dentsply International, Inc., 399 F.3d 181 (2006), prosecutions occur and succeed, as they should. ${ }^{56}$ And, with luck, in the not too distant future, the Supreme Court will see the wisdom of formally reversing Northern Pacific and judging tying cases under the rule of reason as well, completing the movement from the harsh judicial treatment of the 1960 s to a more balanced view of vertical relationships and vertical restraints -- based on sensible economics.

\section{Predatory pricing.}

Prior to the 1970s, the "treatment of predatory pricing in the cases and the literature...has

\footnotetext{
${ }^{55}$ For a discussion of one worthwhile challenge in the 1980s, see White (1985).

${ }^{56}$ On Microsoft, see Rubinfeld (2004); on Dentsply, see Katz (2002, 2009).
} 
commonly suffered from two interrelated defects: failure to delineate clearly and correctly what practices should constitute the offense, and exaggerated fears that large firms will be inclined to engage in it." (Areeda and Turner 1975, pp. 697-698) Similar defects could be ascribed to allegations of price discrimination (where predation claims were often also lurking, implicitly if not explicitly), as exemplified by FTC enforcement actions and Supreme Court decisions (e.g., Utah Pie Co. v. Continental Baking Co. et al., 386 U.S. 685 (1967). Common to enforcement actions and judicial decisions were findings of "pricing below cost" as incriminating behavior, where "below cost" was either vaguely defined or defined as below average costs (which usually also meant using some arbitrary method of distributing joint costs across multiple products, such as using the relative sales revenues of the products as the relative weights).

Academic work to clarify predatory issues, and to cast doubt on the empirical frequency of predation, began at "Chicago" (under Aaron Director's influence) in the late 1950s. ${ }^{57}$ The paradigm of envisioning predation as an "investment" (an initial sacrifice) and then a subsequent recoupment period (higher prices permitting a profits return on the initial investment) became clear. Building on this base, Areeda and Turner (1975) offered a powerful critique ${ }^{58}$ and a proposal that pricing at or above marginal cost (with average variable cost serving as a proxy for the usually unmeasurable marginal cost) should generally be considered as a "safe harbor" for firms in alleged predatory situations. This subsequently became known as the "Areeda-Turner rule". ${ }^{59}$

${ }^{57}$ See for example, McGee (1958) and Telser (1966); see also Task Force (1969) and Peltzman (2005). McGee also called into question the factual issue of whether Standard Oil of New Jersey had actually engaged in the predatory practices in the late 19th century that had formed the basis of the Supreme Court's decision finding it guilty of Section 2 violations (U.S. v. Standard Oil Co. of N.J. et al., 221 U.S. 1 (1911)) and for the company's subsequent forced break-up into a number of constituent companies.

${ }^{58}$ Recall that Turner had a Ph.D. in economics as well as a law degree and thus can legitimately be included in this list of economists' accomplishments.

59 The Areeda-Turner rule spawned a flurry of economist critiques and refinements. See, for example, Scherer (1976), Williamson (1977), Baumol (1979), Joskow and Klevorick (1979), and 
Subsequent legal decisions and especially Supreme Court decisions -- in Matsushita Electric Industrial Corp., Ltd., et al. v. Zenith Radio Corp., et al., 475 U.S. 574 (1986); ${ }^{60}$ Brooke Group, Ltd. v. Brown \& Williamson Tobacco Corp., U.S. (1993); ${ }^{61}$ and most recently in Weyerhaeuser Co. v. Ross-Simmons Hardwood Lumber Co., Inc. 127 S. Ct. 1069 (2007) -- have clearly been influenced by the investment-plus-recoupment paradigm and by the price-above-marginal-cost test. ${ }^{62}$

It is worth noting that, at about the same time that economists in the antitrust area were clarifying notions of predation, economists in regulatory areas (see, e.g., Baumol 1968; Baumol and Walton 1973) were writing about similar pricing issues in those areas and were nudging regulatory criteria and decisions away from the use of fully distributed cost and instead toward the use of incremental costs.

\section{$\underline{\text { V. Conclusion }}$}

It is clear that the influence of economics on antitrust legal decisions and policy over the past two to three decades has been substantial. This influence has occurred through developments in economics thinking, through the elevation of economists' status and positions at the DOJ and the FTC, and through the wider participation of economists in antitrust litigation generally.

Reasonable economists can differ as to the wisdom of some of these developments and as to the particular stringency of enforcement (or lack thereof) over the past few decades. But few can

\footnotetext{
Brodley and Hay (1981).

${ }^{60}$ For a discussion, see Elzinga (1999).

${ }^{61}$ For a discussion, see Burnett (1999).

${ }^{62}$ As will be argued below, however, the strict investment-plus-recoupment" approach is not sufficiently nuanced, since it does not encompass strategic approaches, such as a company's being willing to absorb a loss through below-marginal-cost pricing in one market, without recoupment, so as to gain a reputation for being aggressive and thereby discouraging entry (or expansion by rivals) in other markets (and thus the recoupment is effectively achieved in those other markets).
} 
argue with the proposition that economists' influence has increased. ${ }^{63}$

Nirvana has not yet arrived, however. There are at least four areas where further creative economics thinking and influence could encourage better antitrust decisions and policy. First, there is the ongoing dilemma of how to take into account the efficiencies that may accompany a proposed merger. The tradeoffs of the potential welfare losses from heightened market power as against the potential improved efficiencies have been apparent at least since Williamson (1968). But improved efficiencies are easy to promise and may be difficult to deliver; ${ }^{64}$ and "unscrambling the eggs" of a merger a few years after it has been approved and the efficiencies have failed to appear may be difficult or impossible (in addition to the difficulties of even trying to measure whether efficiencies have indeed appeared or not).

Second, unilateral predatory behavior needs a more nuanced approach. Current antitrust decisions -- as enunciated in Brooke Group Ltd. v. Brown \& Williamson Tobacco Corp., 509 U.S. 209 (1992), and recently re-affirmed in Weyerhaeuser Co. v. Ross-Simmons Lumber Co., 127 S. Ct. 1069 (2007) -- portray predation as a low-price strategy that is strictly a narrow investment involving

63 There is an interesting question -- which will be addressed only briefly here -- as to why the legal profession -- at the enforcement agencies, in private practice, and in the judiciary -- were willing to accept the expanded influence of economics and economists on their legal terrain. A few potential (and potentially complementary) explanations can be offered: First, the ideas may well have been too good to be ignored. Second, some agency leaders (e.g., Donald Turner, Thomas Kauper, William Baxter, James Miller, Robert Pitofsky) had come from an academic background and may have been interested in the broader perspective that an academic background often encourages; the same might be said of some influential judges (e.g., Richard Posner, Frank Easterbrook, and Stephen Breyer. Also, some of these same individuals had advanced training in economics and/or had advanced economics instincts. Third, especially for lawyers in private practice, the addition of economists in cases meant a greater need for lawyers (and billable hours) to ride herd on these extra participants. Fourth, special programs to improve the economics literacy of the judiciary may have had some effects. Further exploration of these ideas will have to await another day.

${ }^{64}$ For an example, see Kwoka and White (2004b). However, for a closer call on these tradeoff issues, see Baker (2004). 
an initial investment in below-marginal-cost pricing that will be recouped in higher prices and profits after the target firm departs from the market. Lost in this narrow approach are the larger issues of whether achieving a reputation for below-cost pricing might deter future entry or deter fringe firms that might otherwise be inclined to be mavericks. Achieving this reputation could make the action worthwhile, even if the specific instance under scrutiny would (when the analysis is narrowly confined to only the costs and returns in this instance) not appear to be profitable. ${ }^{65}$ Further, applying even this narrow cost-benefit paradigm to non-price behavior has proved difficult. $^{66}$ And the issue of bundled discounts, as portrayed in LePage's Inc. v. 3M, 324 F.3d 141 (2003), has roiled antitrust thinking. ${ }^{67}$

Clear economics thinking can surely help. For example, the concept of "no economic sense" -- that a price or non-price action should be condemned if it made no economic sense for the firm undertaking it unless the target firm disappeared from the market or would otherwise be disciplined - is surely one direction that is worth pursuing (although it does not encompass the strategic reputation issues raised above). ${ }^{68}$ There may well be other directions that good economics thinking can uncover.

Third, the issue of market definition in Sherman Act Section 2 monopolization cases remains in an unsatisfactory state. This problem is at the center of the so-called "cellophane fallacy": The Supreme Court in U.S. v. E.I. du Pont de Nemours \& Co., 351 U.S. 377 (1956), decided that the relevant market for analyzing du Pont's market share was "flexible wrapping materials", in which du

${ }^{65}$ See, for example, Brodley et al. (2000).

${ }^{66}$ See, for example, the discussion in Edlin and Farrell (2004).

67 The AMC Report, for example, devoted a surprisingly large amount of space to the decision and to remedies. For a discussion of LePage's, see, for example, Roberts (2009).

${ }^{68}$ See, for example, Werden (2006) and Ordover and Willig (1981, 1999). 
Pont's cellophane had less than a 20\% share, rather than cellophane itself, which du Pont dominated.

The Court reached this decision by noticing that du Pont was constrained from raising its cellophane prices by the likelihood that it would lose too many customers to sellers of other flexible wrapping materials. The difficulty with this approach (as was pointed out by Stocking and Mueller 1955) is that a monopolist of cellophane would be expected to maintain a price that would have exactly this property. Accordingly, this "test" cannot distinguish between a monopolist of cellophane and a competitor in the flexible wrapping materials market. ${ }^{69}$ Nevertheless, this test frequently appears in the market definition parts of monopolization decisions. ${ }^{70}$

The economics textbook notion of what distinguishes a monopoly often stresses the excess profits that are being earned by the monopoly (and this was a large part of Stocking and Mueller's (1955) claim that du Pont did have market power ${ }^{71}$ ); but, as was discussed above, since the mid 1980s accounting profits have largely disappeared from economists' efforts to test the S-C-P paradigm, and the same concerns would plague most profits-based efforts at market definition for these Section 2 cases. Clearly, more creative thinking is warranted. ${ }^{72}$

Fourth, economists need to lead the effort to make a retrospective assessment of the efficacy of antitrust enforcement, especially merger enforcement. Are the DOJ and FTC drawing the right "lines" in their decisions as to whether to challenge or approve mergers?

${ }^{69}$ Although the Court's "test" would appear to be similar to the Merger Guidelines' SSNIP test, the crucial difference is that the SSNIP test is intended to be forward looking, in order to answer the question, "Will this merger create or enhance market power," whereas the Court was applying it in the context of trying to determine whether du Pont already had market power. See White (2007).

${ }^{70}$ See the discussion in White (2008); see also U.S. v. Visa and MasterCard, 163 F. Supp. 2d 322 (2001), 344 F.3d 229 (2003).

${ }^{71}$ Stocking and Mueller (1955) also argued that du Pont's prices for cellophane did not move in response to changes in other flexible wrapping materials' prices.

${ }^{72}$ Some suggestions are offered in White (2008). 
The answer to this question cannot be learned from examining the number of challenges to mergers per year, or examining the characteristics of the mergers that are challenged or of the mergers that are successfully challenged (since one can never know the "counter-factual" with respect to those mergers). But post-merger pricing studies of those mergers that are allowed to proceed -- especially those mergers that are "close calls" (as indicated by whether the agencies made a "second request" to ask for additional information from the merger proponents) -- should yield useful information. If these studies indicate that post-merger prices have not increased (cet. par.), then merger policy may have been too strict; if the studies instead indicate that post-merger prices have increased significantly, then merger policy has been too lenient. ${ }^{73}$

In sum, antitrust economics still has important tasks before it. I hope that there will be supply that will respond to this demand.

\section{$\underline{\text { References }}$}

Adelman, Morris A., "The A \& P Case," American Economic Review, 39 (May 1949a), pp. 280283.

Adelman, Morris A., "The A \& P Case: A Study in Applied Economic Theory," Quarterly Journal of Economics, 63 (May 1949b), pp. 238-257.

Adelman, Morris A., "Economic Aspects of the Bethlehem Opinion," Virginia Law Review, 45 (1959), pp. 684-696.

Adelman, Morris A., A\&P: A Study in Price-Cost Behavior and Public Policy. Cambridge, Mass.: Harvard University Press, 1959.

American Bar Association (ABA), "Report of the ABA Commission to Study the Federal Trade Commission," September 15, 1968; reprinted in Journal of Reprints for Antitrust Law and Economics, 1 (Winter 1969), pp. 885-1009.

\footnotetext{
${ }^{73}$ Other observations and suggestions with regard to current merger enforcement can be found in White (2006a).
} 
American Economic Association, Readings in the Social Control of Industry. Philadelphia: Blakiston, 1942.

Antitrust Modernization Commission, Report and Recommendations. Washington, D.C.: AMC, April 2007.

Areeda, Philip and Donald F. Turner, "Predatory Pricing and Related Practices under Section 2 of the Sherman Act," Harvard Law Review, 88 (February 1975), pp. 697 -733.

Attorney General's National Committee to Study the Antitrust Laws, Report (March 31, 1955); reprinted in Journal of Reprints for Antitrust Law and Economics, 11 (1980), pp. 1-405.

Audretsch, David B. and John J. Siegfried, eds., Empirical Studies in Industrial Organization: Essays in Honor of Leonard W. Weiss, Dordrecht: Kluwer Academic Publishers, 1992.

Bain, Joe S., "Relation of Profit Rate to Industry Concentration: American Manufacturing, 19361940," Quarterly Journal of Economics, 65 (May 1951), pp. 293-324.

Bain, Joe S., "Economies of Scale, Concentration, and the Condition of Entry in Twenty Manufacturing Industries," American Economic Review, 44 (March 1954), pp. 15-39.

Bain, Joe S., Barriers to New Competition. Cambridge, Mass.: Harvard University Press, 1956.

Bain, Joe S., Industrial Organization. New York: John Wiley \& Sons, 1959.

Baker, Jonathan B., "Efficiencies and High Concentration: Heinz Proposes to Acquire Beech-Nut (2001)," in John E. Kwoka, Jr., and Lawrence J. White, eds., The Antitrust Revolution, 4th edn. New York: Oxford University Press, 2004, pp. 150-169.

Barnett, Thomas O., "Competition Law and Policy Modernization: Lessons from the U.S. CommonLaw Experience," Presentation to the Lisbon Conference on Competition Law and Economics, Lisbon, Portugal, November 16, 2007; accessible at:

http://www.usdoj.gov/atr/public/speeches/227755.htm

Baron, David P., "Design of Regulatory Mechanisms and Institutions," in Richard Schmalensee and Robert D. Willig, eds., Handbook of Industrial Organization, vol. 2. Amsterdam: North-Holland, 1989, pp. 1347-1447.

Baumol, William J., "Reasonable Rules for Rate Regulation: Plausible Policies for an Imperfect World," in Almarin Phillips and Oliver E. Williamson, eds., Prices: Issues in Theory, Practice, and Public Policy. Philadelphia: University of Pennsylvania Press, 1968, pp. 101-123.

Baumol, William J., "Quasi-Permanence of Price Reductions: A Policy of Preventing Predatory 
Pricing," Yale Law Journal, 87 (November 1979), pp. 1-26.

Baumol, William J. and Alfred G. Walton, "Full Costing, Competition and Regulatory Practice," Yale Law Journal, 82 (March 1973), pp. 639-655.

Benston, George J., "Accounting Numbers and Economic Values," Antitrust Bulletin, 27 (Spring 1982), pp. 161-215.

Blaisdell, Thomas C., The Federal Trade Commission: An Experiment in the Control of Business. New York: Columbia University Press, 1932.

Bork, Robert H., "Vertical Integration and the Sherman Act: The Legal History of an Economic Misconception," University of Chicago Law Review, 22 (Autumn 1954), pp. 157-201.

Bork, Robert H., The Antitrust Paradox: A Policy at War with Itself. New York: Basic Books, 1978.

Bork, Robert H. and Ward S. Bowman, Jr., "The Crisis in Antitrust," Columbia Law Review, 65 (March 1965), pp. 363-376.

Bothwell, James L. and Theodore E. Keeler, "Profits, Market Structure, and Portfolio Risk," in Robert T. Masson and P. David Qualls, eds., Essays in Industrial Organization in Honor of Joe S. Bain. Cambridge, Mass.: Ballinger, 1974, pp. 71-88.

Bowman, Ward S., Jr., "The Prerequisites and Effects of Resale Price maintenance," University of Chicago Law Review, 22 (Summer 1955), pp. 825-873.

Bowman, Ward S., Jr., "Tying Arrangements and the Leverage Problem," Yale Law Journal, (November 1957), pp. 19-36.

Bowman, Ward S., Jr., Patent and Antitrust Law: A Legal and Economic Appraisal. Chicago: University of Chicago Press, 1973.

Brodley, Joseph F., Patrick Bolton, and Michael H. Riordon, "Predatory Pricing: Strategic Theory and Legal Policy," Georgetown Law Journal, 88 (August 2000), pp. 2239-2330.

Brodley, Joseph F. and George A. Hay, "Predatory Pricing: Competing Economic Theories and the Evolution of Legal Standards," Cornell Law Review, 66 (April 1981), pp. 738-803.

Brannman, Lance, J. Douglas Klein, and Leonard W. Weiss, "The Price Effects of Increased Competition in Auction Markets," Review of Economics and Statistics, 69 (February 1987), pp. 2432.

Brannman, Lance and J. Douglas Klein, "The Effectiveness and Stability of Highway Bid-Rigging," 
in David B. Audretsch and John J. Siegfried, eds., Empirical Studies in Industrial Organization: Essays in Honor of Leonard W. Weiss. Dordrecht: Kluwer Academic Publishers, 1992, pp. 61-75.

Braeutigam, Ronald R., "Optimal Policies for Natural Monopolies," in Richard Schmalensee and Robert D. Willig, eds., Handbook of Industrial Organization, vol. 2. Amsterdam: North Holland, 1989, Ch. 23.

Bresnahan, Timothy F., "Empirical Studies of Industries with Market Power," in Richard Schmalensee and Robert Willig, eds., Handbook of Industrial Organization, Vol. 2. Amsterdam: North-Holland, 1989, pp. 1011-1057.

Brock, Gerald W., "Dominant Firm Response to Competitive Challenge: Peripheral Manufacturers' Suits against IBM (1979-1983)," in John E. Kwoka, Jr., and Lawrence J. White, eds., The Antitrust Revolution, New York: HarperCollins, 1989, pp. 160-182.

Buccirossi, Paolo, ed., Handbook of Antitrust. Cambridge, Mass.: MIT Press, 2007.

Burnett, William B., "Predation by a Nondominant Firm: The Liggett Case (1993)," in John E. Kwoka, Jr., and Lawrence J. White, eds., The Antitrust Revolution: Economics, Competition, and Policy, 3rd edn. New York: Oxford University Press, 1999, pp. 239-263.

Burns, Arthur R., "The Organization of Industry and the Theory of Prices," Journal of Political Economy, 45 (October 1937), pp. 662-680.

Burstein, Meyer L., "The Economics of Tie-In Sales," Review of Economics and Statistics, 42 (February 1960a), pp. 68-73.

Burstein, Meyer L., "A Theory of Full-Line Forcing," Northwestern University Law Review, (March-April 1960b), pp. 62-95.

Carlton, Dennis W. and Ken Heyer, "The Year in Review: Economics at the Antitrust Division, 2006-2007," Review of Industrial Organization, 31 (September 2007), pp.

Caves, Richard E., Air Transport and Its Regulators. Cambridge, Mass.: Harvard University Press, 1962.

Caves, Richard E., "In Praise of the Old I.O." International Journal of Industrial Organization, 25 (February 2007), pp. 1-12.

Chamberlin, Edward H., "Duopoly: Value Where Sellers Are Few," Quarterly Journal of Economics, (November 1929), pp. 63-100.

Chamberlin, Edward H., The Theory of Monopolistic Competition, 7th edn. Cambridge, Mass: 
Harvard University Press, 1956.

Clarkson, Kenneth W. and Timothy J. Muris, "Commission Performance, Incentives, and Behavior," in Kenneth W. Clarkson and Timothy J. Muris, eds., The Federal Trade Commission since 1970. Cambridge: Cambridge University Press, 1981, pp. 280-306.

Coate, Malcolm B., "Empirical Analysis of Merger Enforcement under the 1992 Merger Guidelines," Review of Industrial Organization, 27 (December 2005), pp. 279-301.

Coate, Malcolm B. and Shawn W. Ulrick, "Transparency at the Federal Trade Commission: The Horizontal Merger Review Process 1996-2003," Bureau of Economics, Federal Trade Commission, February 2005. Accessible at: http://www.ftc.gov/os/2005/02/0502economicissues.pdf

Collins, Norman R. and Lee E. Preston, Concentration and Price-Cost Margins in Manufacturing. Berkeley: University of California Press, 1968.

Collins, Norman R. and Lee E. Preston, "Price-Cost Margins and Industry Structure," Review of Economics and Statistics, 51 (August 1969), pp. 271-286.

Comanor, William S. and Thomas A. Wilson, "Advertising, Market Structure, and Performance," Review of Economics and Statistics, 49 (November 1967), pp. 423-440.

Comanor, William S. and Thomas A. Wilson, Advertising and Market Power. Cambridge, Mass.: Harvard University Press, 1974.

Cox, Steven R., "Advertising Restrictions among Professionals: Bates v. State Bar of Arizona (1977), in John E. Kwoka, Jr., and Lawrence J. White, eds., The Antitrust Revolution, New York: HarperCollins, 1989, pp.134-159.

DeLamarter, Richard T., Big Blue: IBM's Use and Abuse of Power. New York: Dodd, Mead, 1986.

Demsetz, Harold, "Industry, Structure, Market Rivalry, and Public Policy," Journal of Law \& Economics, 16 (April 1973), pp. 1-90.

Demsetz, Harold, "Two Systems of Belief about Monopoly," in Harvey J. Goldschmid, H. Michael Mann, and J. Fred Weston, Industrial Concentration: The New Learning. New York: Columbia University Press, 1974, pp. 164-184.

Dobson, Douglas C., William G. Shepherd, and Robert D. Stoner, "Strategic Capacity Preemption: DuPont (Titanium Dioxide) (1982)," in John E. Kwoka, Jr., and Lawrence J. White, eds., The Antitrust Revolution: The Role of Economics, 2nd edn. New York: HarperCollins, 1994, pp. 157188. 
De Jong, Henry W. and William G. Shepherd, eds., Pioneers of Industrial Organization: How the Economics of Competition and Monopoly Took Shape. Cheltenham: Edward Elgar, 2007.

Eads, George C., "Competition in the Domestic Trunk Airline Industry: Too Much or Too Little?" in Almarin Phillips, ed., Promoting Competition in Regulated Markets. Washington, D.C.: Brookings, 1975, pp. 13-54.

Edlin, Aaron S. and Joseph Farrell, "The American Airlines Case: A Chance to Clarify Predation Policy (2001)," in John E. Kwoka, Jr., and Lawrence J. White, eds., The Antitrust Revolution, 4th edn. New York: Oxford University Press, 2004, pp. 502-527.

Edwards, Corwin, "Can the Antitrust Laws Preserve Competition?" American Economic Review, 30 (March 1940, supplement), pp. 164-179.

Eisner, Marc Allen, Antitrust and the Triumph of Economics: Institutions, Expertise, and Policy Change. Chapel Hill: University of North Carolina Press, 1991.

Elzinga, Kenneth G., "Collusive Predation: Matsushita v. Zenith (1986)," in John E. Kwoka, Jr., and Lawrence J. White, eds., The Antitrust Revolution: Economics, Competition, and Policy, 3rd edn. New York: Oxford University Press, 1999, pp. 220-238.

Elzinga, Kenneth G. and Thomas F. Hogarty, "The Problem of Geographic Market Delineation," Antitrust Bulletin, 18 (1973), pp. 45-81.

Esposito, Louis and Frances F. Esposito, "Foreign Competition and Domestic Industry Profitability," Review of Economics and Statistics, 53 (November 1971), pp. 343-353.

Evans, David S., ed., Breaking up Bell: Essays on Industrial Organization and Regulation. New York: North Holland, 1983.

Federal Trade Commission, "FTC History: Bureau of Economics Contributions to Law Enforcement, Research, and Economic Knowledge and Policy," Roundtable with Former Directors of the Bureau of Economics, Federal Trade Commission, September 4, 2003; available at: http://www.ftc.gov/be/workshops/directorsconference/docs/directorstableGOOD.pdf

Fellner, William J. Competition Among the Few. New York: Knopf, 1949.

Fisher, Franklin M., "The Misuse of Accounting Rates of Return: Reply," American Economic Review, 74 (June 1984), pp. 509-517.

Fisher, Franklin M., "On the Mis-Use of the Profits-Sales Ratio to Infer Monopoly Power," $\underline{\text { RAND }}$ Journal of Economics, 18 (Autumn 1987), pp. 384-396. 
Fisher, Franklin M. and John J. McGowan, "On the Misuse of Accounting Rates of Return to Infer Monopoly Profits," American Economic Review, 73 (March 1983), pp. 82-97.

Fisher, Franklin M., John J. McGowan, and Joen E. Greenwood, Folded, Spindled, and Mutilated: Economic Analysis and U.S. v. IBM. Cambridge, Mass.: MIT Press, 1983.

Geroski, Paul A., "What Do We Know about Entry?" International Journal of Industrial Organization, 13 (December 1995), pp. 421-440.

Goldschmid, Harvey J., H. Michael Mann, and J. Fred Weston, Industrial Concentration: The New Learning. New York: Columbia University Press, 1974.

Green, Mark J., The Closed Enterprise System. New York: Grossman, 1972.

Grether, Ewald T., "Industrial Organization: Past History and Future Problems," American Economic Review, 60 (May 1970), pp. 83-89.

Gruenspecht, Howard K., and Lester B. Lave, "The Economics of Health, Safety, and Environmental Regulation," in Richard Schmalensee and Robert D. Willig, eds., Handbook of Industrial Organization, vol. 2. Amsterdam: North Holland, 1989, pp. 1507-1550.

Hahn, Robert W., Robert E. Litan, and Jesse Gurman, "Bringing More Competition to Real Estate Brokerage," Real Estate Law Journal, 35 (Summer 2006), pp. 86-118.

Hay, George A., "Practices That Facilitate Cooperation: The Ethyl Case," in John E. Kwoka, Jr., and Lawrence J. White, eds., The Antitrust Revolution: Economics, Competition, and Policy, 3rd edn. New York: Oxford University Press, 1999, pp. 182-201.

Henderson, Gerard C., The Federal Trade Commission: A Study in Administrative Law and Procedure. New Haven: Yale University Press, 1924

Hilke, John C. and Philip B. Nelson, "Nonprice Predation and Attempted Monopolization: The Coffee (General Foods) Case," in John E. Kwoka, Jr., and Lawrence J. White, eds., The Antitrust Revolution, New York: HarperCollins, 1989, pp. 208-240.

Homan, Paul T., "Preface," in American Economic Association, Readings in the Social Control of Industry. Philadelphia: Blakiston, 1942, pp. v-vi.

Horowitz, Ira, "Market Definition in Antitrust Analysis: A Regression Based Approach," Southern Economic Journal, 48 (1981), pp. 1-16.

Houthakker, Hendrik S., "Expert Testimony by Economists: What Makes It Effective?" in Daniel J. Slottje, ed., The Role of the Academic Economist in Litigation Support. Amsterdam: Elsevier, 1999, 
pp. 1-10.

Joskow, Paul L. and Alvin K. Klevorick, "A Framework for Analyzing Predatory Pricing Policy," Yale Law Journal, 89 (December 1979), pp. 213-270.

Joskow, Paul L. and Nancy L. Rose, "The Effects of Economic Regulation," in Richard Schmalensee and Robert D. Willig, eds., Handbook of Industrial Organization, vol. 2. Amsterdam: North Holland, 1989, pp. 1459-1506.

Katz, Michael L., "Recent Antitrust Enforcement Actions by the U.S. Department of Justice: A Selective Survey of Economic Issues," Review of Industrial Organization, 21 (December 2002), pp. 373-397.

Katz, Michael L., "Exclusive Dealing and Antitrust Exclusion: U.S. v. Dentsply," in John E. Kwoka, Jr., and Lawrence J. White, eds., The Antitrust Revolution, 5th edn. New York: Oxford University Press, 2009, forthcoming.

Katz, Michael L. and Carl Shapiro, "Critical Loss: Let's Tell the Whole Story," Antitrust, 17 (2003), pp. 49-56.

Katzmann, Robert A., Regulatory Bureaucracy: The Federal Trade Commission and Antitrust Policy. Cambridge, Mass.: MIT Press, 1980.

Kauper, Thomas E., "The Role of Economic Analysis in the Antitrust Division before and after the Establishment of the Economic Policy Office: A Lawyer's View," Antitrust Bulletin, 29 (Spring 1984), pp. 111-132.

Kaysen, Carl, United States $v$. United Shoe Machinery Corporation: An Economic Analysis of an Anti-Trust Case. Cambridge, Mass.: Harvard University Press, 1956.

Kaysen, Carl and Donald F. Turner, Antitrust Policy: An Economic and Legal Analysis. Cambridge, Mass.: Harvard University Press, 1959.

Kovacic, William E., "The Influence of Economics on Antitrust," Economic Inquiry, 30 (April 1992), pp. 294-306.

Kwoka, John E., Jr., and Lawrence J. White, eds., The Antitrust Revolution. New York, HarperCollins, 1989.

Kwoka, John E., Jr., and Lawrence J. White, eds., The Antitrust Revolution: The Role of Economics, 2nd edn. New York: HarperCollins, 1994.

Kwoka, John E., Jr., and Lawrence J. White, eds., The Antitrust Revolution: Economics, 
Competition, and Policy, 3rd edn. New York: Oxford University Press, 1999.

Kwoka, John E., Jr., and Lawrence J. White, eds., The Antitrust Revolution: Economics, Competition, and Policy, 4th edn. New York: Oxford University Press, 2004a.

Kwoka, John E., Jr., and Lawrence J. White, "Manifest Destiny? The Union Pacific and Southern Pacific Railroad Merger (1996)," in John E. Kwoka, Jr., and Lawrence J. White, eds., The Antitrust Revolution: Economics, Competition, and Policy, 4th edn. New York: Oxford University Press, 2004b, pp. 24-51.

Kwoka, John E., Jr., and Lawrence J. White, eds., The Antitrust Revolution, 5th edn. New York: Oxford University Press, 2009, forthcoming.

Lafontaine, Francine and Margaret Slade, "Vertical Integration and Firm Boundaries: The Evidence," Journal of Economic Literature, 45 (September 2007), pp. 629-685.

Leddy, Mark, "Recent Merger Cases Reflect Revolution in Antitrust Policy," Legal Times, November 3, 1986, p. 2.

Letwin, William, Law and Economic Policy in America. New York: Random House, 1965.

Lustgarten, Steven H., "The Impact of Buyer Concentration on Manufacturing Industries," Review of Economics and Statistics 57 (May 1975), pp. 125-132.

Lynk, William J., "Tying and Exclusive Dealing: Jefferson Parish Hospital v. Hyde," in John E. Kwoka, Jr., and Lawrence J. White, eds., The Antitrust Revolution: Economics, Competition, and Policy, 3rd. edn. New York: Oxford University Press, 1999, pp. 342-363.

Mann, H. Michael, "Seller Concentration, Barriers to Entry, and Rates of Return in Thirty Industries, 1950-1960," Review of Economics and Statistics, 48 (August 1966), pp. 296-307.

Mann, H. Michael, "The New York Stock Exchange: A Cartel at the End of Its Reign," in Almarin Phillips, ed., Promoting Competition in Regulated Markets. Washington, D.C.: Brookings, 1975, pp. 301-327.

Marshall, Alfred, Principles of Economics, 8th edn. London: Macmillan, 1920.

Marvel, Howard P., "Exclusive Dealing," Journal of Law \& Economics, 25 (April 1982, pp. 1-25.

Marvel, Howard P., "How Fair is Fair Trade?" Contemporary Policy Issues, 3 (Spring 1985), pp. $23-$ 36.

Marvel, Howard P. and Stephen McCafferty, "Resale Price Maintenance and Quality Certification," 
Rand Journal of Economics, 15 (Autumn 1984), pp. 346-359.

Marvel, Howard P. and Stephen McCafferty, "The Welfare Effects of Resale Price Maintenance," Journal of Law \& Economics, 28 (May 1985), pp. 363-379.

Marvel, Howard P. and Stephen McCafferty, "The Political Economy of Resale Price Maintenance," Journal of Political Economy, 94 (October 1986), pp. 1074-1095.

Mason, Edward S., "Price and Production Policies of Large-Scale Enterprise," American Economic Review, 29 (March 1939 supplement), pp. 61-74.

Mason, Edward S., Economic Concentration and the Monopoly Problem. Cambridge, Mass.: Harvard University Press, 1959.

Mathewson, G. Frank, and Ralph A. Winter, "An Economic Theory of Vertical Restraints," Rand Journal of Economics, 15 (Spring 1984), pp. 27-38.

McGee, John S., In Defense of Industrial Concentration. New York: Praeger, 1971.

McGee, John S., "Predatory Price Cutting: The Standard Oil (N.J.) Case," Journal of Law \& Economics, 1 (October 1958), pp. 137-169.

Meyer, John R., Merton J. Peck, John Stenason, and Charles Zwick, Competition and the Transportation Industries of the United States. Cambridge, Mass.: Harvard University Press, 1959.

Mueller, Willard F., "The Revival of Economics at the FTC in the 1960s," Review of Industrial Organization, 25 (August 2004), pp. 91-105.

Nicholls, William H., "The Tobacco Case of 1946," American Economic Review, 39 (May 1949), pp. 284-296.

Nicols, Alfred, "The Cement Case," American Economic Review, 39 (May 1949), pp. 297-310.

Noll, Roger G., "Economic Perspectives on the Politics of Regulation," in Richard Schmalensee and Robert D. Willig, eds., Handbook of Industrial Organization, vol. 2. Amsterdam: North Holland, 1989, pp. 1253-1287.

Noll, Roger G., and Owen, Bruce M. "The Anticompetitive Uses of Regulation: United States v. AT\&T (1982)," in John E. Kwoka, Jr., and Lawrence J. White, eds., The Antitrust Revolution: The Role of Economics, 2nd edn. New York: HarperCollins, 1994, pp. 328-375.

Ordover, Janusz A. and Robert D. Willig, "An Economic Definition of Predation: Pricing and Product Innovation," Yale Law Journal, 91 (November 1981), pp. 8-53. 
Ordover, Janusz, and Robert Willig. "Economics and the 1992 Merger Guidelines: A Brief Survey." Review of Industrial Organization, 8 (March 1993), pp. 139-150.

Ordover, Janusz A. and Robert D. Willig, "Access and Bundling in High-Technology Markets," in Jeffrey A. Eisenach and Thomas M. Lenard, eds., Competition, Innovation, and the Microsoft Monopoly: Antitrust in the Digital Marketplace. Boston: Kluwer, 1999, pp. 103-128.

Peltzman, Sam, "Aaron Director's Influence on Antitrust Policy," Journal of Law \& Economics, 43 (October 2005), pp. 313-330.

Peltzman, Sam, "George Joseph Stigler," in Henry W. de Jong and William G. Shepherd, eds., Pioneers of Industrial Organization: How the Economics of Competition and Monopoly Took Shape. Cheltenham: Edward Elgar, 2007, pp. 239-244.

Perry, Martin K., "Vertical Integration: Determinants and Effects," in Richard Schmalensee and Robert D. Willig, eds., Handbook of Industrial Organization, vol. 2. Amsterdam: North-Holland, 1989, pp. 183-255.

Posner, Richard A., "A Program for the Antitrust Division," University of Chicago Law Review, 38 (Spring 1971), pp. 500-536.

Posner, Richard A., Antitrust Law: An Economic Perspective. Chicago: University of Chicago Press, 1976.

Preston, Lee, "Territorial Restraints: GTE Sylvania (1977)," in John E. Kwoka, Jr., and Lawrence J. White, eds., The Antitrust Revolution: The Role of Economics, 2nd edn. New York: HarperCollins, pp. 311-327.

Roberts, Gary L., "The Use of Bundled Rebates by a Dominant Firm: LePage's v 3M," in John E. Kwoka, Jr., and Lawrence J. White, eds., The Antitrust Revolution, 5th edn. New York: Oxford University Press, 2009, forthcoming.

Rubinfeld, Daniel L., "Maintenance of Monopoly: U.S. v. Microsoft," in John E. Kwoka, Jr., and Lawrence J. White, eds., The Antitrust Revolution, 4th edn. New York: Oxford University Press, 2004, pp. 476-501.

Salinger, Michael A., Pauline M. Ippolito, and Joel L. Schrag, "Economics at the FTC: Pharmaceutical Patent Dispute Settlements and Behavioral Economics," Review of Industrial Organization 31 (September 2007), pp.

Salop, Steven C. and Lawrence J. White. 1986. "Economic Analysis of Private Antitrust Litigation," Georgetown Law Journal, 74 (April), 201-263. 
Salop, Steven C., and White, Lawrence J., "Private Antitrust Litigation: An Introduction and Framework," in White, Lawrence J., ed., Antitrust Litigation: New Evidence, New Learning. Cambridge, Mass.: MIT University Press, 1988, pp. 3-60.

Schelling, Thomas C., The Strategy of Conflict. Cambridge, Mass.: Harvard University Press, 1960.

Scherer, F.M., "Predatory Pricing and the Sherman Act: A Comment," Harvard Law Review, 89 (March 1976), pp. 869-890.

Scherer, F.M., "The Welfare Economics of Product Variety: An Application to the Ready-to-Eat Cereals Industry," Journal of Industrial Economics, 28 (December 1979), pp. 113-134.

Scherer, F.M., "Sunlight and Sunset at the Federal Trade Commission," Administrative Law Review, 42 (Fall 1990), pp. 461-487.

Schmalensee, Richard L., "Entry Deterrence in the Ready-to-Eat Cereal Industry," Bell Journal of Economics, 9 (Autumn 1978), pp. 305-327.

Schmalensee, Richard, "Inter-Industry Studies of Structure and Performance," in Richard Schmalensee and Robert Willig, eds., Handbook of Industrial Organization, Vol. 2. Amsterdam: North-Holland, 1989, pp. 951-1009.

Schmalensee, Richard and Robert D. Willig, eds., Handbook of Industrial Organization, vol. 1. Amsterdam: North Holland, 1989a.

Schmalensee, Richard and Robert D. Willig, eds., Handbook of Industrial Organization, vol. 2. Amsterdam: North Holland, 1989b.

Schumpter, Joseph S., History of Economic Analysis. New York: Oxford University Press, 1954.

Shepherd, William G., "Edward S. Mason," in Henry W. de Jong and William G. Shepherd, eds., Pioneers of Industrial Organization: How the Economics of Competition and Monopoly Took Shape. Cheltenham: Edward Elgar, 2007, pp. 209-210.

Shubik, Martin, Strategy and Market Structure. New York: Wiley, 1959.

Stevens, W.H.S., "The Trade Commission Act," American Economic Review, 4 (December 1914), pp. 840-855.

Siegfried, John J. and Laurie Beth Evans, "Entry and Exit in United States Manufacturing Industries from 1977 to 1982," in: David B. Audretsch and John J. Siegfried, eds., Empirical Studies in Industrial Organization: Essays in Honor of Leonard W. Weiss. Dordrecht: Kluwer Academic 
Publishers, 1992, pp. 253-273.

Siegfried, John J. and Laurie Beth Evans, "Empirical Studies of Entry and Exit: A Survey of the Evidence," Review of Industrial Organization, 9 (April 1994), pp. 121-155.

Stevens, W.H.S., "The Trade Commission Act," American Economic Review, 4 (December 1914), pp. 840-855.

Stevens, W.H.S., "The Federal Trade Commission's Contribution to Industrial and Economic Analysis: The Work of the Economic Division," George Washington Law Review, 8 (JanuaryFebruary 1940), pp. 545-580.

Stigler, George J. "A Theory of Oligopoly," Journal of Political Economy, 72 (February 1964), pp. 55-69.

Stigler, George J., "The Dominant Firm and the Inverted Price Umbrella," Journal of Law \& Economics, 8 (October 1965), pp. 167-172.

Stocking, George W. and Willard F. Mueller, "The Cellophane Case and the New Competition," American Economic Review, 45 (March 1955), pp. 29-63.

Task Force, "Report of the Task Force on Productivity and Competition" (the Stigler Report), February 18, 1969, reprinted in Journal of Reprints for Antitrust Law and Economics, 1 (Winter 1969), pp. 829-881.

Telser, Lester G. "Why Should Manufacturers Want Fair Trade?" Journal of Law \& Economics 3 (October 1960), pp. 86-105.

Telser, Lester G., "Cutthroat Competition and the Long Purse," Journal of Law \& Economics, 9 (October 1966), pp. 259-277.

Viscusi, W. Kip, John M. Vernon, and Joseph E. Harrington, Jr., Economics of Regulation and Antitrust, 3rd edn. Cambridge, Mass.: MIT Press, 2000.

Warren-Boulton, Frederick R., "Resale Price Maintenance Reexamined: Monsanto v. Spray-Rite," in John E. Kwoka, Jr., and Lawrence J. White, eds., The Antitrust Revolution: Economics, Competition, and Policy. New York: Oxford University Press, 1999, pp. 364-385.

Weaver, Suzanne, Decision to Prosecute: Organization and Public Policy in the Antitrust Division. Cambridge, Mass.: MIT Press, 1977.

Weiss, Leonard W., "Quantitative Studies of Industrial Organization," in Michael D. Intriligator, ed., Frontiers of Quantitative Economics. Amsterdam: North-Holland, 1971, pp. 362-403. 
Weiss, Leonard W., "The Concentration-Profits Relationship and Antitrust," in Harvey J. Goldschmid, H. Michael Mann, and J. Fred Weston, Industrial Concentration: The New Learning. New York: Columbia University Press, 1974, pp. 184-233.

Weiss, Leonard W., "Antitrust in the Electric Power Industry," in Almarin Phillips, ed., Promoting Competition in Regulated Markets. Washington, D.C.: Brookings, 1975, pp. 135-173.

Weiss, Leonard W., ed., Concentration and Price. Cambridge, Mass.: MIT Press, 1989.

Werden, Gregory J., "The 1982 Merger Guidelines and the Ascent of the Hypothetical Monopolist Paradigm," Antitrust Law Journal 71 (2003), pp. 253-276.

Werden, Gregory J., "Identifying Exclusionary Conduct under Section 2: The 'No Economic Sense Test,"' Antitrust Law Journal, 73 (No. 2, 2006), pp. 413-434.

Werden, Gregory J. and Luke Froeb. "The Effects of Mergers in Differentiated Products Industries: Logit Demand and Merger Policy," Journal of Law, Economics, and Organization 10 (October 1994), pp. 407-426.

Werden, Gregory J. and Luke M. Froeb, "Unilateral Competitive Effects of Horizontal Mergers," in Paolo Buccirossi, ed., Handbook of Antitrust Economics. Cambridge, Mass.: MIT Press, 2007, pp. 43-104.

White, Lawrence J., "A Legal Attack on Oligopoly Pricing: The Automobile Fleet Sales Case," Journal of Economic Issues, 9 (June 1975), pp. 271-283.

White, Lawrence J., "Searching for the Critical Concentration Ratio: An Application of the 'Switching of Regimes' Technique," in Stephen M. Goldfeld and Richard E. Quandt, eds., Studies in Non-Linear Estimation. Cambridge: Ballinger, 1976, pp. 61-76.

White, Lawrence J. "Vertical Restraints in Antitrust Law: A Coherent Model." Antitrust Bulletin 26 (Summer 1981), pp. 327-345.

White, Lawrence J., "Introduction to the Morning Session," Antitrust Bulletin, 29 (Spring 1984), pp. $1-2$.

White, Lawrence J., "Antitrust and Video Markets: The Merger of Showtime and the Movie Channel as a Case Study," in Eli Noam, ed., Video Media Competition: Regulation, Economics, Competition. New York: Columbia University Press, 1985, pp. 338-363.

White, Lawrence J., "The Revolution in Antitrust Analysis of Vertical Relationships: How Did We Get from There to Here?" in Robert J. Larner and James W. Meehan, eds., Economics and Antitrust 
Policy. New York: Quorum, 1989, pp. 103-121.

White, Lawrence J., "Economic Analysis in Antitrust Litigation Support : The Federal Trade Commission's 1986 Challenge to the Proposed Merger of Coca-Cola and Dr Pepper," in Daniel J. Slottje, ed., The Role of the Academic Economist in Litigation Support. Amsterdam: Elsevier, 1999, pp. 11-30.

White, Lawrence J. "Present at the Beginning of a New Era for Antitrust: Reflections on 19821983." Review of Industrial Organization 16 (March 2000), pp. 131-149.

White, Lawrence J., "Horizontal Antitrust Merger Enforcement: Some Historical Perspectives, Some Current Observations," prepared for the Antitrust Modernization Commission's Economists' Roundtable on Merger Enforcement, January 19, 2006a; available at:

White, Lawrence J., "The Residential Real Estate Brokerage Industry: What Would More Vigorous Competition Look Like?", Real Estate Law Journal, 35 (Summer 2006b), pp. 11-32.

White, Lawrence J., "Market Power and Market Definition in Monopolization Cases: A Paradigm is Missing," in Wayne D. Collins, ed. Issues in Competition Law and Policy. Chicago: American Bar Association, 2008.

White House Task Force, "Report of the White House Task Force on Antitrust Policy" (the Neal Report), July 5, 1968, reprinted in Journal of Reprints for Antitrust Law and Economics, 1 (Winter 1969), pp. 633-826.

Wilcox, Clair, Competition and Monopoly in American Industry. Washington, D.C.: Temporary National Economic Committee, 1940.

Williamson, Oliver E., "Economies as an Antitrust Defense: The Welfare Tradeoffs." American Economic Review, 58 (March 1968), pp. 18-36.

Williamson, Oliver E., "Predatory Pricing: A Strategic and Welfare Analysis," Yale Law Journal, 87 (December 1977), pp. 284-340.

Williamson, Oliver E., "Economics and Antitrust Enforcement: Transition Years," Antitrust, 17 (Spring 2003), pp. 61-65. 